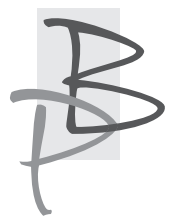

Joanna Zajkowska*

Uniwersytet Kardynała Stefana Wyszyńskiego

https://orcid.org/0000-0002-9567-4598

\title{
Między „brulionem”, raptularzem a dziełem literackim - czyli co Wiktor Gomulicki napisał w Wenecji. Wstępne rozpoznania i sugestie badawcze
}

Streszczenie: Niniejsze studium omawia nigdzie dotąd niepublikowany manuskrypt Wiktora Gomulickiego - nieprzeznaczony dla czytelniczego oka - zapis wrażeń z podróży, zatytułowany: Notatki z podróży do Włoch (Wiedeń - Wenecja). Wysłany we wrześniu 1888 roku jako delegat na trzynasty kongres literacki w Wenecji pisarz i poeta wykorzystał swoją podróż bardzo twórczo. Literackim efektem wojaży są: pisane na bieżąco w 1888 roku Listy z Wenecji publikowane w „Kurierze Warszawskim”, cykl Z pieśni weneckich I-III, który ukazał się w zbiorze poetyckim autora Nowe pieśni (1895) oraz najbardziej literacko opracowane - Obrazki weneckie z 1896 roku. Te wszystkie utwory są udokumentowane - ukazały się w obiegu czytelniczym, stały się obiektem recenzji w epoce oraz naukowej refleksji współcześnie.

Przechowywany w dziale rękopiśmienniczym Biblioteki Ossolineum we Wrocławiu, pod sygnaturą I/5432, notesik z zapiskami Gomulickiego (12 centymetrów długości i 8 centymetrów szerokości) jest arcyciekawym

\footnotetext{
Joanna Zajkowska - dr hab., adiunkt w Katedrze Pozytywizmu Instytutu Filologii Polskiej Uniwersytetu Kardynała Stefana Wyszyńskiego w Warszawie. Autorka dwóch monografii: Twórczość poetycka Wiktora Gomulickiego wobec tradycji literackiej i współczesności (Warszawa 2010) oraz Na obrzeżach nowoczesności. O powieściopisarstwie Artura Gruszeckiego (Warszawa 2016), a także wielu artykułów w czasopismach i publikacjach zbiorowych.
} 
przykładem intymistyki - ten niewielki zeszycik pozwalał pisarzowi na dokonywanie podróżniczych impresji. Postaram się wykazać, jaka jest zależność między literackim materiałem znanym nam z publikacji autorskich a osobistym dokumentem z podróży wrażliwego literata.

Słowa-klucze: podróżopisarstwo, intymistyka, list z podróży, reportaż, „brulion", rękopis, Wiktor Gomulicki Wenecja.

\section{Between the "drafting", rapporteur, and literary work - that is what Wiktor Gomulicki wrote in Venice. Initial diagnoses and research suggestions}

Summary: The article discusses the manuscript by Wiktor Gomulicki, which was never published before and has been stored in the Manuscript Section at the Ossolineum Library in Wrocław (sig. 1/5432). It is very small $(12 \mathrm{~cm} \times 8 \mathrm{~cm}$ ) inmost notebook where the poet wrote down all his impressions during his stay in Venice, where he had arrived as a depute on the 13th Literary Congress in 1888. It is entiteled: Notatki z podróży do Włoch (Wiedeń - Wenecja) [Notes from a journey to Italy (Vienna - Venice)].

The author of the paper decided to collate the intimate notes with well known literary works of Wiktor Gomulicki, which were published after his voyage and deal with the same recollections of Venice: Listy z Wenecji [Letter from Venice] edited in "Kurier Warszawski” in 1888, poetry cycle Z pieśni weneckich I-III [From Songs of Venice I-III] (1895) and the most precious Obrazki weneckie [Pictures from Venice] (1896).

Key words: notes from journey, manuscript, rapporteur, note-paper, impressions, Wiktor Gomulicki, Venice. 
W 299 numerze „Tygodnika Ilustrowanego” z 1888 roku, w dziale: Silva rerum, pojawiła się informacja:

Na międzynarodowy kongres literacki, rozpoczęty już przed kilku dniami w Wenecji, z literatów polskich udają się Wiktor Gomulicki z Warszawy i Władysław Mickiewicz z Paryża ${ }^{1}$.

Był to 22 września, i rzeczywiście od tygodnia (od 15 września 1888) w Wenecji obradował trzynasty kongres literacki. I właśnie tego dnia, w numerze 298, w notce Od redakcji, przeczytać można było następujące doniesienie:

P. Wiktor Gomulicki, poeta i powieściopisarz utalentowany, wytrawny znawca sztuki, współpracownik naszego pisma, udał się na kongres międzynarodowy literacki do Wenecji, skąd otrzymywać od niego będziemy listy tak o samym kongresie, jak i o innych sprawach donioślejszego znaczenia².

Jednak dociekliwy czytelnik musiał czuć się rozczarowany - w żadnym kolejnym numerze pisma nie było śladu korespondencji poety. Regularnie bowiem ukazywały się one, pod wspólnym tytułem: Listy z Wenecji w... „Kurierze Warszawskim"3.

Gomulickiego podróż do Włoch, na mało w istocie znaczący kongres literacki - artystycznie okazała się nadzwyczaj płodną.

1 Silva rerum literackie, „Tygodnik Ilustrowany” 1888, nr 299, s. 191

2 Od redakcji, „Tygodnik Ilustrowany” 1888, nr 298, s. 162.

3 Pierwszy list ukazał się tam już 17 września 1888 roku, w sobotę, na pierwszej i drugiej stronie numeru 270. Zatytułowany był dosyć intrygująco: Obrazek groszowy w dukatowej oprawie i był poświęcony pierwszym wrażeniom pisarza z Wenecji i z kongresu. Opracowanie bibliograficzne Nowy Korbut, dość nieprecyzyjnie podaje, że Listy z Wenecji publikowane były w „Kurierze Warszawskim" 1888, w numerach 270-276. W rzeczywistości druk nie był tak regularny, a na łamach pisma przeczytać można było sześć listów (niektóre podzielone na dwie części, których publikacja trwała niemal miesiąc - do 14 października 1888 roku). Dla porządku podaję zawartość Listów z Wenecji: nr 270 - I. Obrazek groszowy w dukatowej oprawie; nr 273 - II. Dalszy ciag pracowitego próżnowania, zwanego kongresem literackim; nr 275 - III. Gita di piacere; $\mathrm{nr} 276$ - Dokończenie listu III; nr 281 - IV. Ostatnie dni kongresu; nr 282 - Dokończenie listu IV; nr 285 - V. Szlakiem umartych; nr 292 - VI. W teatrze weneckim. Trzy z wymienionych listów (Gita di piacere (List członka Kongresu literacko-artystycznego), Szlakiem umarlych oraz $W$ teatrze weneckim), z niewielkimi zmianami wejdą do wydanego osiem lat później cyklu: Obrazki weneckie (Warszawa 1896). 
Jej literacki efekt stanowią, wspominane, pisane na bieżąco w 1888 roku Listy z Wenecji publikowane w „Kurierze Warszawskim”, cykl Z pieśni weneckich I-III, który ukazał się dopiero w zbiorze Nowe pieśni ${ }^{4}$ w 1895 roku, oraz najbardziej literacko opracowane - Obrazki weneckie ${ }^{5}$, drukowane w Warszawie w 1896. Te wszystkie utwory są udokumentowane - ukazały się w obiegu czytelniczym, stały się obiektem recenzji ${ }^{6} \mathrm{w}$ epoce oraz naukowej refleksji współcześnie ${ }^{7}$.

Jednakże w Wenecji powstał jeszcze jeden tekst - nie przeznaczony dla czytelniczego oka - intymny zapis wrażeń z podróży, zatytułowany, na potrzeby zbiorów Biblioteki Ossolineum jako Notatki z podróży do Wtoch (Wiedeń - Wenecja). Tekst ten - zachowany w rękopisie jak dotąd nie stał się obiektem

4 W. Gomulicki, Nowe pieśni, Petersburg 1896 [1895]. W III rozdziale tomiku znajduje się podrozdział Z pieśni weneckich I-III (I. Odjazd, II Życie w grobie oraz III. Szajlok) cykl Strofy uliczne i Moja rzeka. Tematycznie, tylko wiersze zanumerowane rzymskim I-III bezpośrednio wiążą się z wenecką peregrynacją Gomulickiego. Warto zauważyć, czego również nie odnotowuje Nowy Korbut, że pierwszy wiersz „,pieśni” Szajlok ukazał się już w 1888 roku na łamach właśnie „Kuriera Warszawskiego", nr 330, s. 1-2.

5 Tegoż, Obrazki weneckie, Warszawa 1896, tu: Zawartość: Dwadzieścia minut u Quadriego. („Tygodnik Powszechny” $1890 \mathrm{nr} 10$ i na.); Gita di piacere; Bazylika. („Kurier Codzienny” 1891, nr 253; „Kurier Niedzielny” 1896, nr 13. Zob. też poz. 60); W trattorii. („Kurier Codzienny” 1890, nr 355); Teatr wenecki; Frutti di mare; Giardini publici. („Tygodnik Powszechny” 1889, nr 5-6); Pozzi. („Kurier Codzienny” 1892, nr 356; „Kurier Lwowski” 1893, nr 1); Gotębie; Szlakiem umarlych. Znowu wypunktować można nieprecyzyjność Nowego Korbuta, który nie odnotowuje, że trzy z wymienionych obrazków pojawiły się już w 1888 roku, w Listach z Wenecji (patrz przypis 3).

6 Nowy Korbut wymienia następujące recenzje Obrazków weneckich: „Biesiada Literacka” 1896 t. 4, s. 432; J. Badeni, „Przegląd Powszechny” 1897, t. 54, s. 118-119; W. Jab. [W. Jabłonowski], „Głos” 1897, nr 12; -mre- [M. Rolle], „Gazeta Lwowska” 1897, nr 193; Hodi [J. Tokarzewicz], „Prawda” 1897, nr 3; R. Zawiliński. „Dział Literacko- Artystyczny Kraju” 1897, nr 4; R. Zawiliński. „Przegląd Literacki” 1897, nr 2; „Wędrowiec” 1897 nr 10. Patrz: Wiktor Gomulicki, [w:] Bibliografia literatury polskiej Nowy Korbut, t. 13, Wrocław, s. 91-111.

7 Prac, które omawiają spuściznę pisarską pobytu Gomulickiego w Wenecji jest stosunkowo niewiele. Są to, podaję w układzie chronologicznym: M. Brahmer, Z dziejów włosko-polskich stosunków kulturalnych, Warszawa 1939, s. 202-203; Z. Szmydtowa: „Obrazki weneckie” W. Gomulickiego, [w:] Prace o literaturze i teatrze ofiarowane Z. Szweykowskiemu, Wrocław 1966, s. 252-260; J. Zajkowska, Między podróżą a poematem - Wiktor Gomulicki w Wenecji, [w:] Podróż i literatura 1864-1914, red. E. Ihnatowicz, Warszawa 2008, s. 449-463; B. Burdziej, Naród w masce. Szekspir, Wenecja i Żydzi w Szajloku (1888) Gomulickiego (s. 171-201) oraz Beata Romanowska, Reportaż sprzed wieku. „Obrazki weneckie” Wiktora Gomulickiego (s. 295-317) - oba w najnowszej pracy zbiorowej poświęconej twórczości Wiktora Gomulickiego: Gomulicki znany i nieznany, red. B. Burdziej, A. Stoff, Torun 2012. 
refleksji, ani badawczego oglądu. Odnotowuje go jedynie bibliografia Nowy Korbut oraz informacja o zbiorach rękopiśmiennych Wiktora Gomulickiego w zasobach Biblioteki Ossolineum ${ }^{8}$.

Pisząc o silnej mizantropii Wiktora Gomulickiego, Tyszkowski informuje: „o ile wiadomo, odbył on raz tylko wojaż do Włoch (Wenecji),co znalazło potwierdzenie w szeregu felietonów, tudzież w notatniku, będącym w posiadaniu Biblioteki Ossolińskich"9.

W niniejszym studium chciałabym przyjrzeć się temu nigdzie nie publikowanemu manuskryptowi, opisać go oraz wstępnie wskazać obszary interpretacyjnej przydatności owych „notatek z podróży”. Można tu bowiem, w pewnym przybliżeniu, mówić o współpracy „filologii edytorskiej” z „filologią interpretującą”. Terminy pochodzą od Stefana Treugutta, który opisywał specyfikę edycji spuścizny po Juliuszu Słowackim ${ }^{10}$. Rzecz jasna w przypadku podróżniczego notatnika Gomulickiego, o którym mowa mamy do czynienia z innym (przede wszystkim - mniejszym!) kalibrem problematyki, ale zasada pozostaje ta sama. Nawet bowiem pobieżny ogląd notatek wskazuje wyraźnie, że zawarte w nich uwagi, spostrzeżenia, a nawet pewne fragmenty zostały wykorzystane przez pisarza zarówno przy tworzeniu Listów, jak i Obrazków, co częściowo będę chciała wykazać czy może - zasygnalizować w niniejszym studium. Jednak pełen obraz dałaby dopiero wnikliwa analiza porównawcza wszystkich trzech dokumentów we wszystkich ich wariantach. Pamiętać należy bowiem, że niektóre „obrazki”, pojawiły się jako część składowa Listów, a inne jeszcze były wcześniej publikowane na łamach różnych pism ${ }^{11}$. Gomulicki niemal zawsze dokonywał korekt stylistycznych na tekście. Dodatkowo - co wykażę, niektóre obrazy

8 Informacja o tym dokumencie - w Nowym Korbucie oraz w notce z K. Tyszkowskiego, Zbiór rękopisów Wiktora Gomulickiego w Bibliotece Zakładu Narodowego im. Ossolińskich we Lwowie, „Kwartalnik Historyczny” 39: 1925, s. 317-321. W Bibliotece Ossolineum we Wrocławiu rzeczony rękopis ma sygnaturę 5432/1, a jego zmikrofilmowana wersja znajduje się także w zbiorach Biblioteki Narodowej w Warszawie. W katalogach notatki Gomulickiego funkcjonują pod tytułem: Notatki z podróży do Włoch (Wiedeń-Wenecja). Wszystkie cytaty w dalszej części studium pochodzą z tego rękopisu, bezpośredni po cytacie podaję numer strony w nawiasie.

9 K. Tyszkowski, dz. cyt., s. 318.

10 Patrz: S. Treugutt, Slowacki i problemy interpretacji filologicznej, [w:] Geniusz wydziedziczony. Studia romantyczne i napoleońskie, red. M. Prussak, Warszawa 1993, s. 285.

11 Patrz przypis 5. 
mają swoje korzenie w czynionych odręcznie, in crudo, zapiskach pisarzadelegata w małym, oliwkowym notatniku.

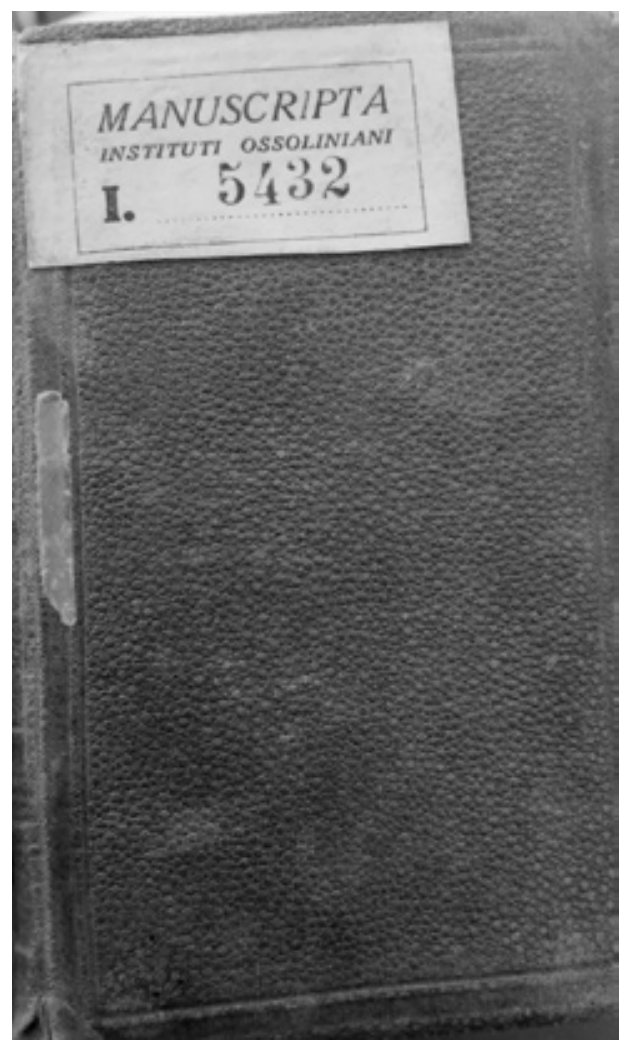

Przechowywany w dziale rękopiśmienniczym Biblioteki Ossolineum we Wrocławiu, pod sygnaturą I/5432 notesik ma 12 centymetrów długości i 8 centymetrów szerokości i można go porównać ze współczesnym drukarskim formatem B7. Ten niewielki notatnik miał więc idealną wielkość, aby zabrać go w podróż: mieścił się bowiem w dłoni, ale także w kieszeni spodni czy marynarki, pozwalając nosić go stale przy sobie i zapisując świeże spostrzeżenia. Notatnik ma 239 stron, zapisywanych dwustronnie, choć niektóre są puste. Nie widać, żeby jakiekolwiek kartki wyrwano. Ponumerowane zostały tylko strony nieparzyste, nawet te puste, więc można przypuszczać, że numeracji dokonano post factum. Regularny zapis prowadzony był zwykłym ołówkiem, do dziś nie wyblakłym, dobrze zachowanym. Jednak na tym zapisie pojawiają się wyraźnie późniejsze skreślenia i zakreślenia, dokonywane bądź ołówkiem, 
bądź czerwoną i niebieską kredką, które nie utrudniają odczytania, a których istnienie wymaga dalszych badań. W paru przypadkach wygląda na to, że Gomulicki przekreśla dużym niebieskim X partie, wykorzystane w Listach, bądź Obrazkach, ale nie jest to niepodważalna zasada, a powyższe przypuszczenie jest jedynie roboczą hipotezą ${ }^{12}$.

Zapis jest stosunkowo „czysty”, bardzo mało skreśleń, czy pomyłek, pismo równe, dosyć czytelne. Co ważne, Autor nie stosował skrótowców, pisał pełnymi słowami, choć nie zawsze zapiski mają charakter pełnozdaniowych wypowiedzi, to taka tendencja jest widoczna. Swoje zapiski, spostrzeżenia oddziela od siebie graficznie krótkimi, poziomymi kreseczkami wyraźnie sygnalizując zmianę tematu.

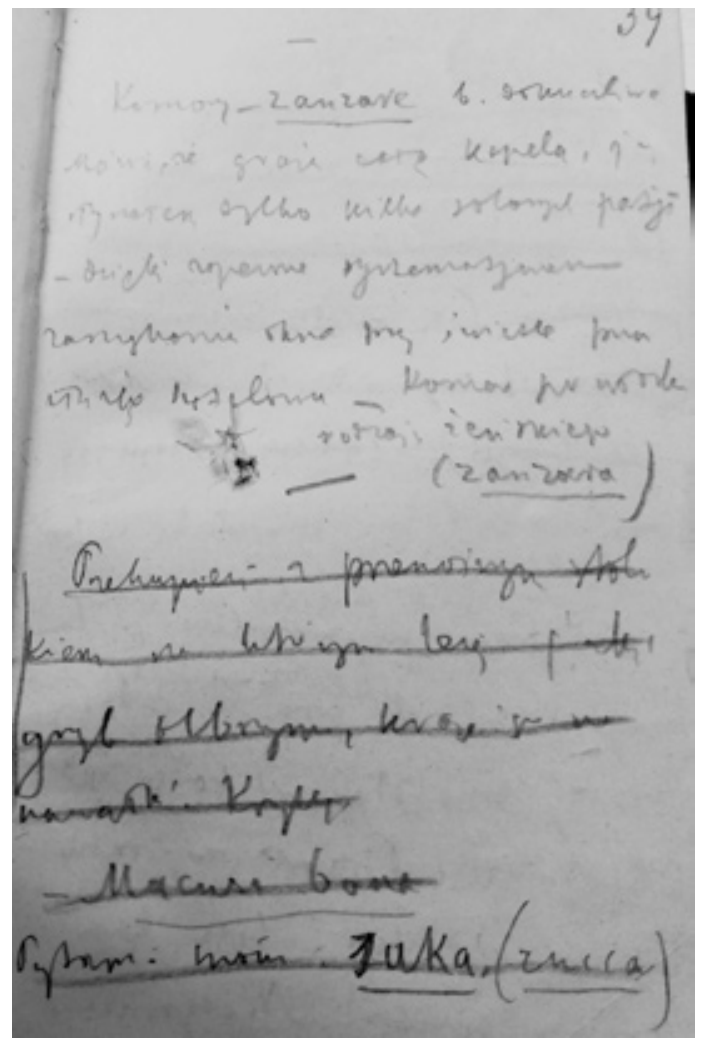

12 Pamiętać trzeba, że pełen zbiór Obrazki weneckie wydany został dopiero po ośmiu latach, a publikacje pojedynczych utworów w prasie pokazują, że powstawały one w ciągu 2-3 lat po odbytej podróży, można więc sądzić, że omawiany notatnik mógł służyć pisarzowi za bazę materiałową do literackiej obróbki, a także rezerwuar wspomnień i wrażeń. 
Te swoiste „akapity” są bardzo różne - zarówno pod względem obszerności (czasami jest to jedno zdanie czy fraza), jak i tematyki. W przeważającej części, będą to rzucane mimochodem spostrzeżenia i wrażenia:

Wszędzie barwy - u dołu pałaców [nieczytelne - J. Z.] pomarańczowe, zielone, szare, czarne, oliwkowe.

W nocy sylwety rysują się wyraziście. (N, 11) [podkr. - W. G.] $]^{13}$

Widać, że pisane „na gorąco”, kiedy to podkreślenie całego wpisu sugeruje rzeczywiste emocje, jakich autor tekstu doświadczał.

Wieniec strasznych głów nad mostem dei Sospiri. Każda inaczej się wykrzywia. $(\mathrm{N}, 31)$ [podkr. - W. G.]

Bywają też jednak i większe objętościowo - stanowiące osobne scenki rodzajowe, które Gomulicki szczególnie cenił:

Chłopak mały, brudny, z gołą głową, typ ulicznika - Signore! signore! - wbiega w bramę i wywija trzy kozły, jeden za drugim - Sico! - a potem rękę wyciąga, żeby mu płacić.... (N, 22) [podkr. - W. G.]

Jednak są też zupełnie obszerne partie, poświęcone ważnym dla autora sprawom. I tak na stronach 134 do 146 pojawiają się uwagi dotyczące malarstwa włoskiego, a konkretnie dzieł sztuki, które Gomulicki musiał oglądać w Wenecji. Pisarz był znanym komentatorem sztuki, czego dawał wyraz chociażby w Kartkach estetycznych drukowanych od 1886 na łamach „Prawdy” Aleksandra Świętochowskiego. Co ciekawe - interesują go konkretne dzieła sztuki, które szczegółowo opisuje na kartkach Notatnika. Pozwolę sobie na jeden przykład:

13 Fragmenty z Notatek z podróży podaję w swoim odczytaniu. Podkreślenia pochodzą od Wiktora Gomulickiego. Wszystkie dalsze cytaty pochodzące z rękopiśmiennych Notatek z podróży (1888) - zapisuję (N, numer strony) 
Assunta. Rozdzielona na 3 części. U góry Bóg i anioła w koronie. W środku M. Boska na obrazie otoczona półkolem aniołków. U dołu lud, młodzieńcy, mężczyźni, starcy, kobiety.

Przeważanie czerwień. Cała suknia M. Boskiej. U dołu dwie postaci męskie w czerwieni. Bóg także płaszczyk czerwony.

Bóg ucięty w połowie, czym tłumaczy się rysunek. Twarz heroicznego, stroskanego, zafrasowanego staruszka. Rozkłada ręce "Chodź moja córko ukochana”. M. Boska, tęga, prosta dziewka z wyrazem spokojnego zadowolenia, bez zapału, podnosi ręce do Boga.

Stoi na obłokach twardych, gipsowych. Potwierdza ich twardość to, że aniołki podpierają je z wysiłkiem.

Tło górnej połowy żółto-złote, przechodzące przy brzegach w pomarańczowy. Główki aniołków blade, rozpromieniają się u góry.

Po malarsku biorąc: pyszny rysunek. M. Boska wyborna, sukienka w fałdach i lekka draperia. Aniołków gromada rozkosznych malców - ciała spalone, włoskie. Buzie niektórych idealne piękne.

Muskulatura obnażonej wyciągniętej ręki młodzieńca u dołu. (N, 134-138) [podkr. - W. G.]

Zapisane w Notatkach wrażenia odnoszą się oczywiście do obraz Tycjana Wniebowzięcie Najświętszej Marii Panny, który powstał w 1518 roku na zlecenie mnichów z kościoła Santa Maria Gloriosa dei Frari. Tam go pewnie widział nasz podróżnik do Wenecji. Na kolejnych stronach pojawią się jeszcze uwagi o dziełach Tycjana Wniebowzięcie Najświętszej Marii Panny, Tintoret$\mathrm{ta}^{14}$, Bonifaccia ${ }^{15}$, Van Dycka ${ }^{16}$, Van Ostade'a ${ }^{17}$, Piazzety ${ }^{18}$, a nawet konkretne dzieła, jak Assunta Pawła Veronese czy jego Gody w Kanie galilejskiej. Prze-

14 Jacopo Tintoretto - włoski malarz i rysownik okresu manieryzmu, jeden z głównych przedstawicieli szkoły weneckiej XVI wieku.

15 Bonifacio Veronese lub Bonifacio Veneziano, właśc. Bonifacio de’ Pitati - włoski malarz późnego renesansu i manieryzmu.

16 Antoon van Dijk, Anthony van Dyck - flamandzki malarz epoki baroku, znany głównie jako autor portretów.

17 Adriaen van Ostade - malarz, rysownik i akwaforcista holenderski.

18 Giovanni Battista Piazzetta - malarz, grafik i rytownik, przedstawiciel weneckiego malarstwa rokokowego. 
analizowanie tych zapisów, sprawdzenie ich estetycznego znawstwa warte jest przemyślenia. Tym bardziej, że uwagi dotyczące malarstwa nie zostały wykorzystane ani w Listach z Wenecji, ani w Obrazkach weneckich. Stanowi więc ważny fragment artystycznego dorobku tej podróży, wart, jak sądzę, głębszej refleksji.

Ponieważ są to notatki podróżnicze, zawierają one stałe w takich sytuacjach elementy: daty (choć tych jest stosunkowo mało i nie odnotowuje ich Gomulicki regularnie), trasy podróży, nazwy miejsc, pałaców, muzeów i innych zabytków. Ów notesik przeradza się także momentami w swoiste rozmówki włosko-polskie, ponieważ podróżnik nieustannie zapisuje nazwy potraw czy elementów włoskiej, egzotycznej dla niego, rzeczywistości. Co ważne, z dużą konsekwencją podkreśla wszystkie zwroty, zdania i nazwy własne pisane po włosku.

W tych momentach przeradza się ów notatnik w rodzaj prywatnego itinerariusza, w którym pomieszcza autor niezbędne w komunikacji słówka, zwroty i wyrażenia; odnotowuje miejscowe zwyczaje związane z posiłkami i życiem codziennym. I tak na przykład na stronie 36 mamy krótki zapis:

Krzyki uliczne:

Acqua fresca con gliaccio!

Figni!

Gazetta de Venezia, Adriatico (wym. Gazyta, syta de wenysa) (N, 36) [podkr. - W. G.]

Zresztą w ogóle widać ogromną wrażliwość Gomulickiego na słowo. Nie tylko mnóstwo jest w tekście spisanych inskrypcji z nagrobków, portretów, a nawet afiszów teatralnych. Pisarz bawi się słowem, zauważa błędy językowe i przeinaczenia, szuka we włoskiej mowie słów podobnych do polskich wyrazów. Ta dziedzina notatek również wymagałaby głębszej, uporządkowanej refleksji.

Często włoskim słowom towarzyszą rysunki, które wyobrażają, przede wszystkim produkty żywnościowe. 


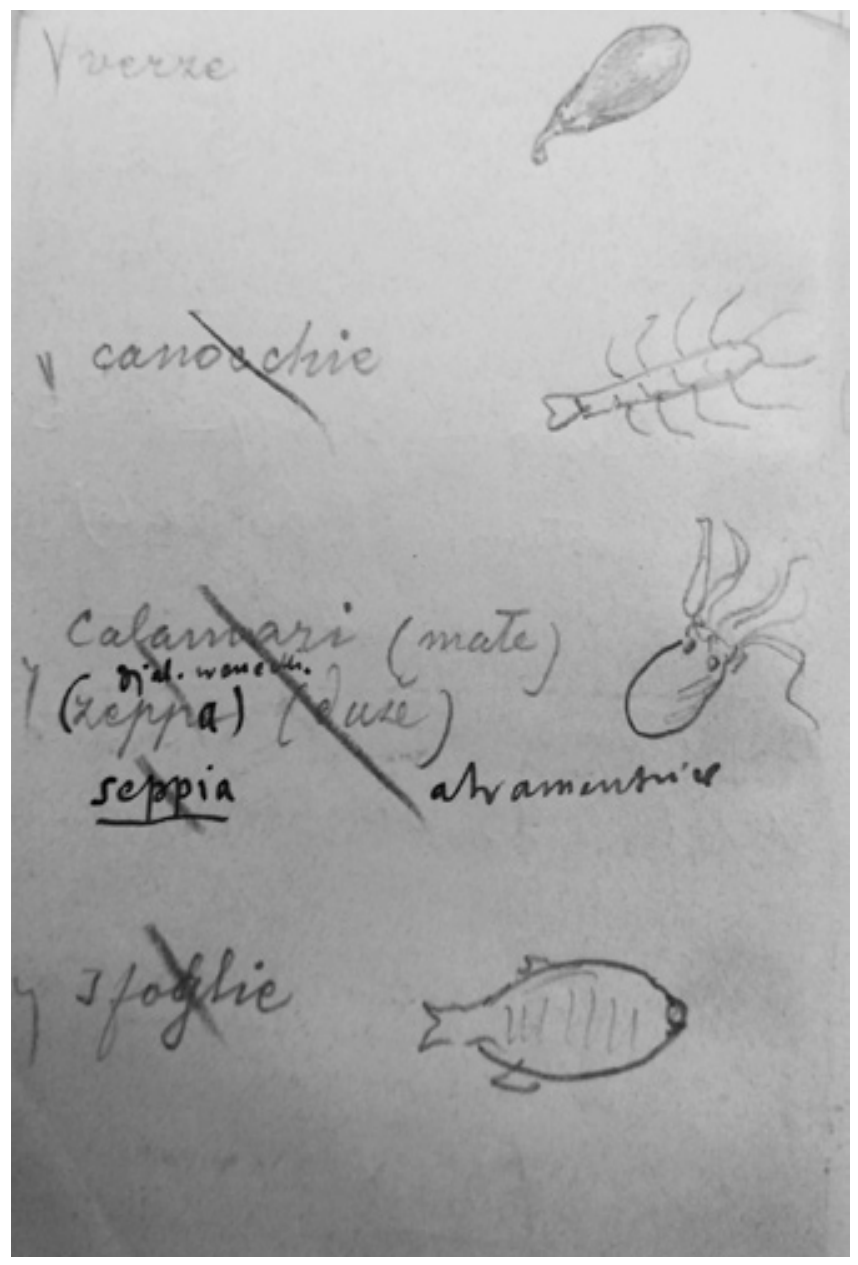

Oczywiście, poza rysunkami - trzeba przyznać, bardzo udanymi, Gomulicki opisuje dość szczegółowe owoce morza. Ma to znowu swoje przełożenie na tekst literacki - sporą część treści z Notatek znajdziemy bowiem w piątym utworze z Obrazków weneckich - Frutti di mare.

Poza intrygującymi kałamarnicami i atramentnicami znajdziemy w Notatkach także rysunki ram okiennych i framug, zdobień żelaznych bram, ale także drobiazgów dnia codziennego. I tak na stronie 71 pojawia się szkic „łyżeczki weneckiej" pożyczonej przez pisarza od gospodyni. Zachwyt nad weneckim jakoby cackiem, zdobnością elementów kończy się nieco humorystycznie, kiedy okazuje się, że to...rosyjska łyżeczka, którą brat gospodarza, śpiewak występujący w Moskwie, ale i w Warszawie, przywiózł ze swoich wojaży. 
Literacko-artystyczne upamiętnienie łyżeczki jest jednak zasadne - to ona „sprowokowała” rozmowę z gospodarzami i to dzięki niej pisarz dowiaduje się o faktach z życia, wydawałoby się, zupełnie obcych osób.

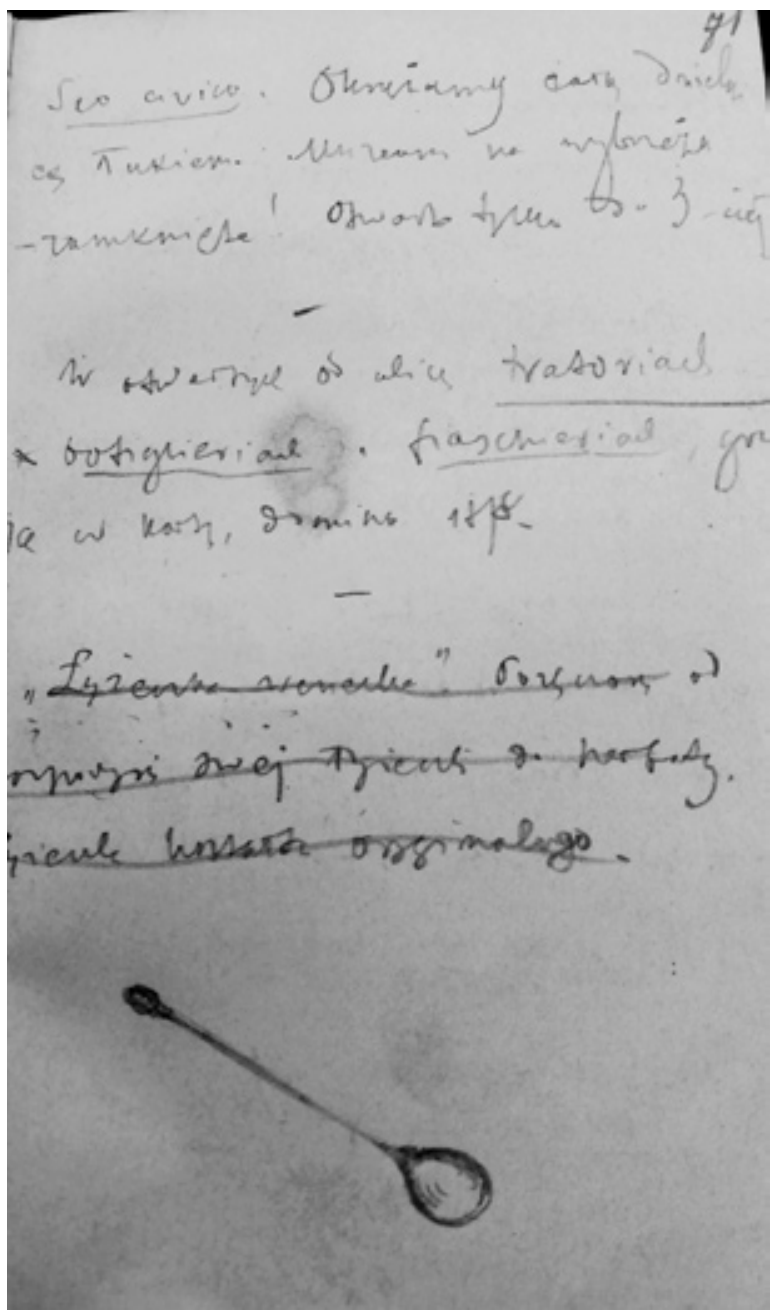


Mamy także na stronach Notatek przedstawienia zabytków, czego najciekawszym przykładem jest umieszczony na stronie 132-133 rysunek kościoła San Giacomo di Rialto oddany z dużą wiernością.

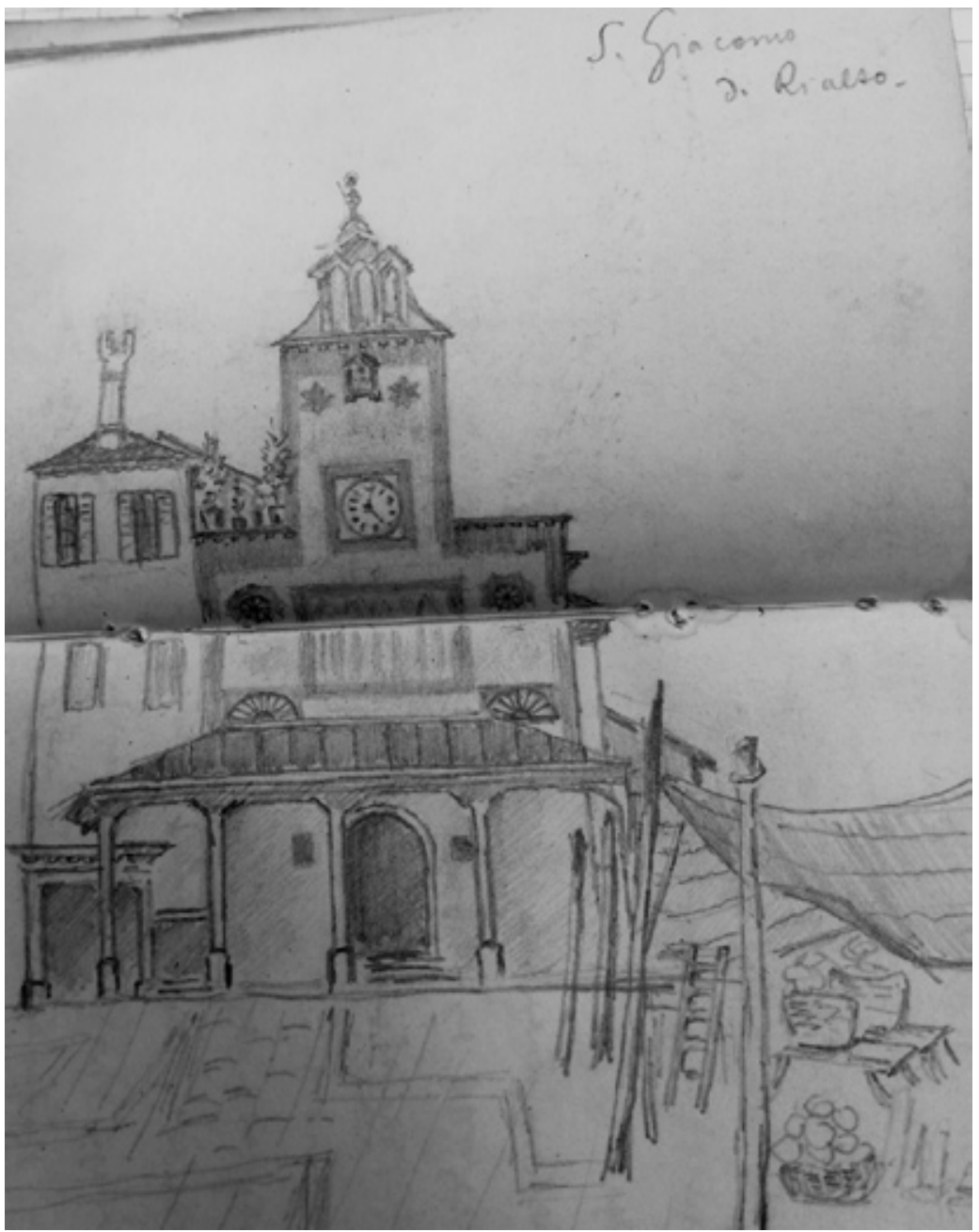

Tak jak w tekście zapisków Gomulicki często pozwala sobie na prezentacje „typów”, co było zgodne z dziewiętnastowiecznym modus operandi, tak i na wielu stronach pojawiają się portrety - zupełnie anonimowe „głowy” mężczyzn i kobiet. Pozostaje pytanie, czy wspominanie rysunki i szkice wyszły spod ołówka autora Notatek. Odpowiedź na to pytanie dziś nie może być jednoznaczna. We wszystkich tekstach Gomulickiego związanych z Wenecją 
pojawia się liczba mnoga czasowników - wiemy, że pisarz nie pojechał na Kongres sam. Jego towarzyszem podróży był Ludomir Ilinicz-Zajdel, warszawski rysownik ilustrator, karykaturzysta i malarz, współpracujący z najważniejszymi wówczas pismami stolicy ${ }^{19}$. Stąd zapewne znajomość z równie dobrze prosperującym podówczas w świecie dziennikarskim Gomulickim, a datować się ona musi od 1882 roku, czego dowodem jest zachowany w zbiorach rękopiśmiennych Biblioteki Narodowej list poety do Zajdla z 1882 roku (rkps IV 5993, k. 48-49). W 1886 roku Zajdel stworzył rycinę do drukowanego w „Tygodniku Ilustrowanym” wiersza Gomulickiego Na Kanonii ${ }^{20}$. Ten sam rysownik był autorem ilustracji do jednego z ważniejszych prozatorskich zbiorów pisarza - tomiku Przy słońcu i przy gazie (1888) ${ }^{21}$, a także nieco później książki dla dzieci Niedziele Romcia (1896). O ile drobiazgi rysunkowe (drobne przedmioty czy szkice rozkładu ulic) mogły zostać narysowane przez pisarza, to wydaje się, że precyzyjnie oddany fronton kościoła przy moście Rialto, jest chyba dziełem wspominanego rysownika.

Zresztą Notatki z podróży do Włoch Gomulickiego, również całkowicie przesądzają, że towarzyszem podróży pisarza był właśnie Zajdel. Bowiem końcowe strony tekstu mają wybitnie raptularzowy charakter. Znajdują się tam skrupulatne rozliczenia z Zajdlem za bilety czy posiłki (strona 239), zapiski rozkładu jazdy pociągów z Wenecji do Wiednia, ale także listę przedwyjazdowych sprawunków i prezentów z Włoch. Dowiadujemy się stąd nie tylko ile pieniędzy i w jakiej gotówce wziął ze sobą pisarz, ale także jakie ubrania i rzeczy ze sobą spakował. Tutaj wszelkie skreślenia znaczą, jak łatwo się domyśleć, że dane przedmioty zostały spakowane, a sprawy do załatwienia - sfinalizowane (strona 237).

Jak dotąd wykazałam, Notatki z podróży do Wtoch Wiktora Gomulickiego sytuują się między raptularzem, notesem do szybkich adnotacji a brulionem w rozumieniu, jaki nadała mu ostatnio Ewa Szczeglacka-Pawłowska. W swej

19 Pełne informacje biograficzne w: Stownik artystów polskich i obcych w Polsce działajacych. Malarze. Rzeźbiarze. graficy, t. III, red. J. M. Białostocka, J. Derwojed, Wrocław-WarszawaKraków-Gdańsk 1979, s. 143-144. Opinię o wspólnej podróży obu potwierdza także znawczyni polskiej ilustracji prasowej i edytorstwa - Janina Wiercińska.

20 W. Gomulicki, Na Kanonii, „Tygodnik Ilustrowany” 1886, nr 202, s. 317.

21 Kwestia, co jedynie sygnalizuję, może wymagać doprecyzowania: na stronie tytułowej tomu nie ma nazwiska ilustratora, natomiast niektóre ilustracje są sygnowane nazwiskiem innego rysownika - Zamarajewa. 
świetnej rozprawie Romantyzm ,brulionowy” badaczka pokazuje - na przykładzie polskich twórców romantycznych - jak należy podchodzić do wszelkich posthumów i jaki jest ich stosunek do oficjalnej, tj. opublikowanej decyzją samych twórców - spuścizny ${ }^{22}$. Aparat badawczy i rozpoznania autorki okazują się wielce przydatne na potrzeby niniejszego studium. Notatki z podróży Gomulickiego uznać przecież można z rodzaj opera posthuma, o tyle ważne, że refleksy tego niepublikowanego notesika, odnaleźć można w dwóch, a nawet trzech ${ }^{22}$ „oficjalnych” poweneckich drukach. Za Szczeglacką-Pawłowską trzeba powiedzieć, że: „Brulion jest początkiem”23.

Można to jednak potwierdzić dopiero po wnikliwej analizie innych dzieł pisarza powstałych po podróży do Wenecji, że podkreślane w notesie były, poza terminami włoskimi, słowa ważne dla literackiej koncepcji oglądanej przestrzeni, swoiste słowa klucze, które ze zdumiewającą frekwencją pojawiają się we wszystkich interesujących mnie tutaj tekstach. Najlepszym tego przykładem jest słowo dzwon. W tym miejscu warto pokazać jakie efekty przynosi literacka praca związana z tym obszarem leksykalnym. Oczywiście przytoczona poniżej lista nie wyczerpuje zagadnienia, a jedynie stanowi drobną egzemplifikację zjawiska.

W Notatkach ${ }^{25}$ dzwony pojawiają się:

Dziwnie smutne wrażenie sprawiają dzwony, [...]. I dzwony te śpiewają tenorowo. W tej chwili (północ) znowu słyszę ten smutny i poważny dźwięk. (N, 17) [podkr. - W. G.]

22 Por. E. Szczeglacka-Pawłowska, Romantyzm „, brulionowy”, Warszawa 2015. Jak pisze autorka: „Romantyzm »brulionowy« jest sformułowaną przeze mnie kategorią interpretacyjną, obejmującą teksty epoki, których autorzy za swojego życia nie opublikowali. [...] W proponowanym projekcie lektury mieszczą się takie „formy”, jak: notesy, raptularze, korespondencja, dzienniki, sztambuchy, albumy, imionniki, a więc twórczość opublikowana ze spuścizny pośmiertnej-opera posthuma romantyzmu." Tamże, s. 21.

23 Tutaj mam na myśli wspominane wcześniej poematy: Z pieśni weneckich. Na stronach Notatek (202-204) znajdują się bowiem wierszowane fragmenty pierwszego z owych poematów pt. Odjazd. Są one niewielkie, ale za to zupełnie czystopisowe, więc trudno dziś zrekonstruować proces twórczy. Wpis wiersza na strony notesika mógł dokonać się post factum. Tę kwestię jedynie sygnalizuję, natomiast znowu - warto przyjrzeć się zależnościom Notatek, także z cyklem Z pieśni weneckich.

24 Tamże, s. 23.

25 Cytaty zapisuję następująco: Notatki z podróży (1888) - (N, numer strony); Listy z Wenecji (1888) (L, numer gazety, numer strony); Obrazki weneckie (Warszawa 1896) - (O, numer strony). 
Dzwon. Komu i na co on dzwoni? Głosem jego przemawia do mnie zgasła przeszłość miasta. (N, 18)

Niezmiernie smutne wrażenie sprawiają dzwony, odzywające się całą masą dźwięku, to tu to ówdzie, prawie nieustannie. Zwłaszcza o późnym wieczorze San Giorgio Maggiore dźwięki rozchodzą się daleko po morzu, jak za umarłych i rzeczywiście jest to hołd oddany Wenecji niedzisiejszej - prawdziwej... (N, 53) [podkr. - W. G.]

Gdziekolwiek i jakkolwiek daleko odsuniesz się, wszędzie i zawsze dogonią cię trzy rzeczy: głos dzwonu, zapach oliwy i Marcia reale ${ }^{26}$. (N, 55) [podkr. - W. G.]

W drugim liście drukowanym w redakcji „Kuriera”, pod przewrotnym tytułem: Dalszy ciąg pracowitego próżnowania, zwanego kongresem literackim, opisując zmęczenie atrakcjami zorganizowanymi dla uczestników Kongresu, pisarz tak podsumuje pełen wrażeń dzień:

W pamięci odzywają się zasłyszane piosenki ludu włoskiego i szumne frazesy mówców kongresowych i muzyka dzwonów, którą Wenecja nieustannie rozbrzmiewa... O zaśnięciu ani myśleć.... (L, nr 273,1)

W Obrazkach motyw dzwonów pojawiać się będzie w najbardziej przejmującym utworze - Szlakiem umartych, powstałym zresztą już w 1888, czego dowodzi publikacja w ramach Listów z Wenecji w „Kurierze Warszawskim”. Przywołuję dwa przykłady:

A tam w górze, wśród lasu wieżyc, kopuł cebulowatych, strzał żelaznych, ku chmurom wymierzonych, jęczy wciąż i modli się i rozpacza żałobna muzyka dzwonów, opłakująca umarłych, urągająca żywym, wieszcząca smutek i zagładę tym nawet, którzy dopiero przyjść mają... $(0,181)$

26 Marcia reale - właściwie: Marcia Reale d'Ordinanza - skomponowany przez Giuseppe Gabetti'ego był oficjalnym hymnem państwowym istniejącego w latach 1861-1946 Królestwa Włoch. Wiktor Gomulicki - w Notatkach z podróży i Listach z Wenecji wielokrotnie wspomina z jaką pasją i częstotliwością odgrywano ten utwór przy różnych okolicznościach, a i bez okoliczności. 
Zadzwoniono. Na wysokiej dzwonnicy opactwa zakołysał się dzwon jeden, potem drugi i trzeci. Spiżowa melodia spłynęła z wysoka, rozlała się po płaszczyźnie cmentarnej, ześlizgnęła na morze, które poniosło ją daleko, daleko... (0, 190)

Szczególnie w tym ostatnim cytacie, w którym pojawia się bardzo poetycki obraz głosu dzwonu ześlizgującego się w morze, słychać, jak się wydaje, wyraźne ślady zapisu z notatek, w których dźwięki dzwonu, „rozchodzą się daleko po morzu", a co ważniejsze - i pozostające w tej samej sferze semantycznej - jest to hołd złożony umarłym.

Podobne zabiegi jak ten, który przedstawiłam powyżej, można zastosować do innych ważnych elementów, z których Gomulicki buduje swoją wizję Wenecji: Bazylika Świętego Marka, nekropolia San Michele, kanały, ulice, mosty, weneckie wysepki, ale także wachlarze czy gołębie, które stale się przewijają na stronicach Notatek, ale i pozostałych interesujących mnie tekstów. Ich wyliczenie, a także przebadanie kontekstów, w których się pojawiają może odpowiedzieć na pytanie o literacką mapę wyobrażonej Wenecji, Wenecji końca XIX wieku, Wenecji Gomulickiego.

Bowiem nie chodzi, znowu powołam się na autorytet Szczeglackiej-Pawłowskiej, o brulionowe porównanie czystopisu do brudnopisu i ustalanie ostatecznej wersji tekstu. Chodzi, jak chce badaczka o kategorię écriture:

Lektura „brulionowa” wydobywa nieoficjalny charakter twórczości, związki sfery pisma z autorem, wyobraźni twórczej i egzystencji27.

W perspektywie „,brulionowej”, jak słusznie zauważa Szczeglacka-Pawłowska - granica pomiędzy życiem a twórczością się zaciera. Ta ostatnia jest bowiem zawsze częścią egzystencji, staje się fragmentem życia konkretnej osoby.

Tak jest w przypadku Gomulickiego i jego niepozornego notatnika od niemal 130 lat przechowywanego w rękopiśmiennych archiwach najpierw samego poety, potem Biblioteki Ossolineum. Notes ów, nie był przeznaczony przez autora do druku. Pisany wyraźnie na własny użytek, z intymnymi notatkami, odważnymi stwierdzeniami, niepoprawnymi politycznie stwierdzeniami -

27 E. Szczeglacka-Pawłowska, dz. cyt., s. 23. 
stanowi świetny przykład literatury „nieoficjalnej”. To tam może sobie pozwolić na komentarze: „Cały kongres wielka - głupota” (N, 27) ${ }^{28}$ i wyśmiewać nabożeństwo, z jakim go celebrowali włoscy organizatorzy. To tam może ponarzekać na brzydotę spotykanych turystów, szczególnie Niemców:

Na przystani [...] pełno Niemców. Niemki efektowne - ale każdej coś brak. Jedna zezowata, druga zęby żółte i rzadkie, [...]

Niemiec wstrętny w gładko opiętej marynarce, twarz małpia, pomarszczona. (N, 119-120).

Pisze szczerze, pewną ręką, a jego uwagi mają bardzo przemyślany charakter. Warto bowiem podkreślić, że podczas lektury Notatek ma się wrażenie, że są też one - dziełem sztuki. W tym prywatnym „brulionie” do głosu dochodzi artysta. Widać to nie tylko w jego świetnym zmyśle obserwacyjnym i szczególnej wrażliwości na kolory ${ }^{29}$, ale także sposobie konstruowania zdań i większych całostek. Niektóre fragmenty - opisy, scenki rodzajowe - mają formę, która sprawia, że bez większych korekt można by je zamieścić w gotowym dziele.

Jak literacko samowystarczalne są podobne fragmenty:

Wenecji potrzeba koniecznie słońca lub księżyca. W dzień pochmurny i w noc bezksiężycową jest ponura jak grób.

Efekt pierwszego dnia dżdżystego, ciemnego. Ponury plac - powietrze niskie, czarne na wygiętych słupach kamiennych - mgła [...] brudno-zielona morska woda pluska. $(\mathrm{N}, 91)$

Lub też w inny miejscu:

28 Ciekawe, że w Notatkach z podróży - Gomulicki w zasadzie nie podejmuje tematu Kongresu literacko-artystycznego, na który był delegatem. W publikowanych w „Kurierze” Listach z Wenecji, da się zauważyć pewną niechęć, czy może raczej dystans do podobnych zgromadzeń, a nade wszystko wątpliwość co do sensowności podobnych przedsięwzięć, ale w prywatnych zapiskach ta kwestia wcale go nie interesuje - poza przytoczony wyżej wykrzyknikiem.

29 Musze tu bardzo wyraźnie stwierdzić, że takiej stałej obserwacji barw i kolorów włoskiego pejzażu nie ma ani w Listach $z$ Wenecji pisarza, ani w nawet w Obrazkach weneckich. Ta wyjątkowość Notatek z podróży wymaga precyzyjniejszego omówienia. 
Morze. Wieczór smutny, wietrzny. Powietrze chłodnawe, nasze. [...] Z powrotem wschód Księżyca. Bania czerwona, poniżej różowa - niezupełnie foremna, na kształt olbrzymiej truskawki. Nadzwyczaj szybko wznosi się w górę - maleje i przybiera barwę pomarańczową, która stopniowo bledniejąc, przechodzi w złotawą i wreszcie w białą. (N, 51) [podkr. - W. G.]

Opisy wschodów księżyca czy weneckiego słońca nocy bez trudu znajdziemy w Obrazkach weneckich, czego przykład poniżej:

Ach! więc to księżyc!

U nas tarcza księżycowa wysuwa się powoli, ociężale - tu, niemal w oczach podskakuje do góry. Dopiero była kopułą minaretu - już jest banią olbrzymią, płomieniem wypełnioną, która, jak balon, szybuje w obłoki. Dopiero była, jak krew czerwona, już pobladła, w karminową, jak płatki centyfolii, przechodząc barwę. [...]

Chwila jeszcze, a ta róża stulistna staje się różą herbacianą. - Barwa jej z karminowej przechodzi w żółtą. Na niebie, które ma tony zielonawe, wygląda, jak dukat olbrzymi, rzucony na sukno bankierskiego kantorka... $(0,49-50)$

Jednak z porównania obu wydaje się, że wersja z Notatek nie jest jedynie jakimś zarysem, z którego po latach powstanie lepszy, stylistycznie wysmakowany opis. Bez zbytniej przesady można uznać, że są one w jakimś sensie alternatywne, że funkcjonują na równych prawach literackiej ważności. Weryfikując więc nieco wcześniejsze spostrzeżenie, że „brulion jest początkiem”, można by się pokusić o stwierdzenie, że niekiedy - sam „brulion” wystarcza. 
Joanna Zajkowska, Między „,brulionem”, raptularzem a dziełem literackim...

\section{Bibliografia}

\section{Podmiotowa}

Gomulicki W., Listy z Wenecji, „Kurier Warszawski” 1888, nr 270 (I. Obrazek groszowy w dukatowej oprawie; nr 273 (Il. Dalszy ciąg pracowitego próżnowania, zwanego kongresem literackim); nr 275-276 (III. Gita di piacere); nr 281-282 (IV. Ostatnie dni kongresu); nr 285 (V. Szlakiem umarłych); nr 292 (VI. W teatrze weneckim).

Gomulicki W., Notatki z podróży do Włoch (Wiedeń - Wenecja), rkps. Bibl. Ossol. Sygn. I/5432.

Gomulicki W., Obrazki weneckie, Warszawa 1896.

\section{Przedmiotowa}

Brahmer M., Z dziejów włosko-polskich stosunków kulturalnych, Warszawa 1939, S. 202-203.

Burdziej B., Naród w masce. Szekspir, Wenecja i Żydzi w "Szajloku” (1888) Gomulickiego, [w:] Gomulicki znany i nieznany, red. B. Burdziej, A. Stoff, Toruń 2012, s. $171-201$.

Romanowska B., Reportaż sprzed wieku. "Obrazki weneckie” Wiktora Gomulickiego, [w:] Gomulicki znany i nieznany, red. B. Burdziej, A. Stoff, Toruń 2012, s. 295-317.

Słownik artystów polskich i obcych w Polsce działających. Malarze. Rzeźbiarze. Graficy, t. III, red. J. M. Białostocka, J. Derwojed, Wrocław-Warszawa-Kraków-Gdańsk 1979.

Szczeglacka-Pawłowska E., Romantyzm „,brulionowy”, Warszawa 2015.

Szmydtowa Z., "Obrazki weneckie” W. Gomulickiego, [w:] Prace o literaturze $i$ teatrze ofiarowane Z. Szweykowskiemu, Wrocław 1966, s. 252-260.

Treugutt S., Słowacki i problemy interpretacji filologicznej, [w:] Geniusz wydziedziczony. Studia romantyczne i napoleońskie, red. M. Prussak, Warszawa 1993.

Tyszkowski K., Zbiór rękopisów Wiktora Gomulickiego w Bibliotece Zakładu Narodowego im. Ossolińskich we Lwowie, „Kwartalnik Historyczny” 39: 1925, s. 317-321. 